\title{
Condensed Matter Physics dalam Kulit Kacang
}

\author{
Muhammad Gaffar A. A \\ First Published: 05 May 2018 \\ Last Edited: 12 September 2018
}

\section{Sekapur Sirih}

Condensed Matter Physics (CMP) menjadi salah satu cabang fisika yang berkembang dengan sangat pesat. Penemuan fenomana, perkembangan konsep, dan teknik semakin meluas, dan bercabang dengan begitu deras. Mungkin pembaca masih ada yang merasa bingung dan asing tentang CMP itu sendiri, yakni tentang apa yang dipelajari, dan tujuannya. Pembaca garis kanan mungkin mempertanyakan karir yang didapatkan dari mempelajari CMP. Sedangkan pembaca garis kiri mungkin mempermasalahkan bahwa pekerjaan CMP tidak se-teoritis dan se-filosofis High Energy Physics(HEP) maupun kosmologi. Tulisan ini tentunya belum dapat mengulas segala hal tentang dunia CMP. Namun penulis akan mencoba mengulas tentang makna dasar CMP itu sendiri dari pengetahuan kecil yang penulis miliki, yang hal ini berhasil membuat penulis banting stir dari keinginan mengenyam pendidikan HEP dan kosmologi. Artikel ini akan mencoba mendiskusikan mengenai hirarki dan paradigma dalam sains, fisika khususnya, dilanjutkan membahas paradigma dan hal yang menuntun perkembangan CMP. Lalu akan mengulas emergent phenomena lebih dalam dan konsekuensi terhadap perkembangan teknologi, yang diulas secara historikal. Lalu melihat sekilas pengaruh komunitas ilmuwan di bidang CMP. Tulisan ini diakhiri dengan membahas sedikit tentang bagaimana mempersiapkan diri untuk mempelejari CMP lebih dalam, dan rekomendasi rancangan studi bagi S-1. Tulisan ini jauh dari sempurna, yang hanya ditulis oleh mahasiswa S-1 semester 6 yang sedang menjalani studi formal mengenai CMP. Tulisan ini ditulis atas keinginan dan semangat tinggi untuk memperkenalkan CMP kepada khalayak ramai, dan berbagi ketertarikan. Semoga tulisan ini bisa menjadi inspirasi bagi yang membaca. Jangan biarkan High Energy Physics dan Kosmologi merebut semua kesenangan! 


\section{Hirarki Saintifik}

Unifikasi dan reduksionisme telah menjadi tulang punggung cita-cita fisika, mungkin hingga saat ini. Segala fenomena alam harus dapat dijelaskan dengan prinsip yang seumum mungkin dengan struktur paling fundamental. Usaha unifikasi dan reduksi yang sukses pada mulanya berawal dari Newton, yang berhasil merumuskan konsep mekanika, dan dilanjutkan dengan proses unifikasi lainnya seperti termodinamika-mekanika oleh Boltzmann, listrik-magnetik oleh Maxwell, proses penyatuan empat gaya fundamental, penyatuan ruang-waktu, dan seterusnya. Pun hingga saat ini fisika terus berjalan diatas cita-cita besar tersebut. Misalnya saja standard model telah sukses pada dunia subatomik, dan relativitas umum juga telah cukup sukses pada dunia kosmologi. Dengan harapan unifikasi, kita dapat menjelaskan dan mengkonstruksi semua fenomena yang mungkin terjadi di alam secara deterministik. Secara sederhana, terlihat dua arah ilmu fisika, semakin kebawah (mengarah ke skala subatomik) dan semakin jauh ke atas (mengarah ke skala kosmos). Kedua area ini bisa dikatakan sebagai pure physics, dikarenakan hampir tidak bersinggungan dengan disiplin ilmu lain. Keberadaan quark, ataupun gaya kuat, hampir tidak memiliki pengaruh sama sekali pada ilmu kimia, dan biologi. Begitu pula dalam konsep medan ruang-waktu tidak memiliki pengaruh terhadap ilmu elektronika.

Namun, kenyataannya tidak ada sains yang bergerak secara sendirian. Kimia membantu penjelasan sintesis protein dan molekular DNA pada biologi, begitupula sel neuron membantu dalam penjelasan cara kerja otak dan dinamikanya bagi neuroscientist, hasil penjelasan dinamika pada otak digunakan pada psikologi digunakan untuk menjelaskan emosi dan perilaku manusia, lalu perilaku manusia menjelaskan konstruksi sosial dalam ilmu sosiologi, dan seterusnya. Hal ini seharusnya berlaku juga dengan Fisika, tentu jika kita melihat pada arah ilmu fisika yang berbeda. Arah ini menjulang dari skala molekul hingga skala makroskopis, inilah yang disebut area many-body physics. Di area inilah dimana fisika bersinggungan dengan kimia dan ilmu material, kimia bersinggungan dengan biologi, dan seterusnya yang akhirnya membentuk hirarki sains. Tentu area ini tidak lagi menjadi pure physics sebagaimana dikatakan diatas, Wolfgang Pauli menyebutnya sebagai dirt physics.

Berbeda dengan pure physics, tujuan utama dari many-body physics bukanlah unifikasi. Salah satunya hal ini dikarenakan many-body physics berada pada area yang prosesnya membutuhkan energi relatif kecil dan skala area yang cukup besar seperti yang ditunjukkan pada gambar 1. Misalnya saja, menyatukan gaya elektromagnetik dan gaya lemah menjadi kesatuan yang disebut sebagai eletroweak membutuhkan energi pada skala ratusan GeV. Fenomena ini tidak mungkin terjadi pada kasus energi yang lebih rendah, seperti pada material maupun sintesis protein misalnya. Sehingga konsep Effective Field Theory[2] dalam fisika statistik cukup sukses menjelaskan mengapa pada skala area tertentu, kita dapat mereduksi derajat kebebasan tanpa harus memperhatikan informasi detail sistem dan interaksi pada area energi yang sangat besar. Tentunya, penemuan Higgs Boson oleh CERN pada tahun 2012 yang lalu tidak memiliki efek yang signifikan pada area many-body physics.

Walaupun pandangan reduksionisme telah menunjukkan kesuksesan di sebagian besar fisika, namun tetap memiliki batasan. Kaum reduksionis tidak dapat bergerak terlalu jauh 

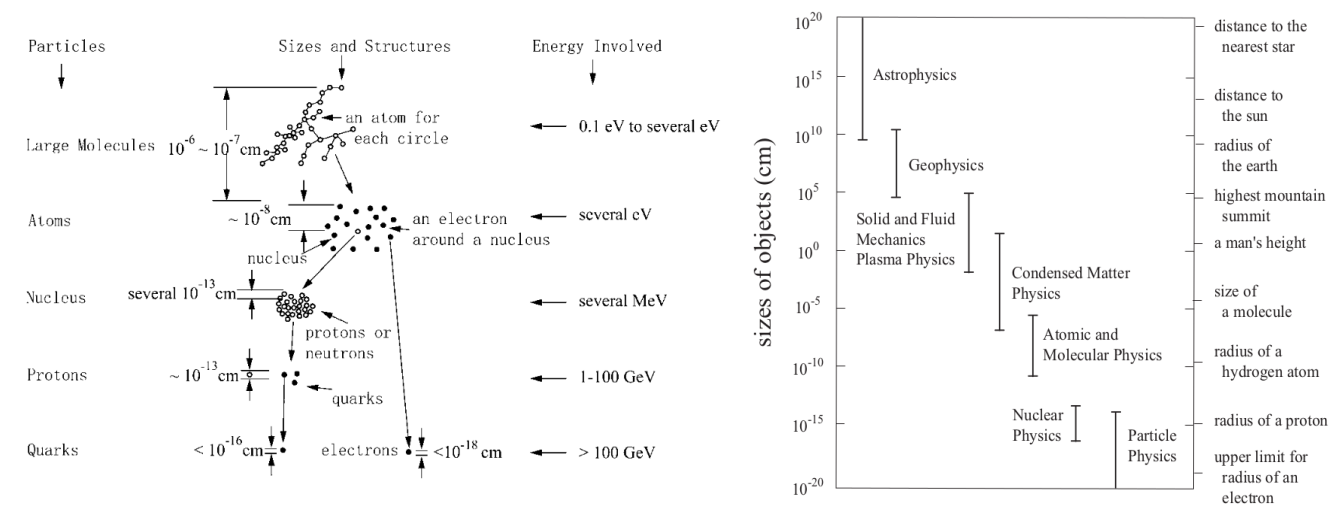

Figure 1: Hirarki Skala Energi (kiri) dan skala area (kanan) dalam Fisika, (Gambar diambil ref.[1]

di bidang ini[1]. Bahkan jika tetap memperhitungkan segala detail dalam sistem (yang mustahil dalam teknologi sekarang), usaha ini hanya akan cepat tumbang melawan usaha yang mencari penjelasan paling sederhana. Jika terdapat dua teori yang dapat menjelaskan suatu fenomena, biasanya yang paling sederhana adalah yang paling populer untuk dipilih sebagai teori yang akan digunakanmetode yang disebut sebagai metode heuristik occams razor ini terbilang cukup sukses dalam pola pikir metode saintifik. Sehingga wajar statistika dan probabilitas menjadi alat paling ampuh, dibanding pendekatan deterministik total.

\section{Paradigma dalam Many-body Physics}

Apakah ini membuat many-body physics dalam area CMP hanyalah menjadi sekedar suatu fisika terapan, yang membuang detail, dan sekedar pendekatan rata-rata dalam skala yang lebih besar? Untuk menjawab hal ini, kita harus memahami bahwa alasan reduksionisme tidak terlalu bekerja dengan baik tidak hanya sekedar bahwa beratnya jika dilakukan kalkulasi secara brutal tanpa aproksimasi. Namun lebih dari itu, pada area ini terdapat fenomena tidak terduga yang hanya muncul hanya akibat hasil kolektif atom, elektron, dan bentuk partikel lainnya dalam sistem, yang tidak dapat dijelaskan jika kita memandang sistem sebagai individu-individu atom yang sekedar ditumpuk. Fenomena yang diluar prediksi ini populernya disebut sebagai Emergent Phenomena. Hal ini juga berlaku untuk kimia, biologi, dan seterusnya. Kompleksitas dalam interkasi berperan pada sistem dengan skala yang besar.

Sehingga naif mengatakan bahwa kimia adalah terapan sekedar terapan dari CMP, biologi adalah terapan kimia, begitupula seterusnya. Faktanya, terdapat paradigma ilmu di masing-masing bidang, perubahan paradigma pada suatu disiplin ilmu tidak akan terlalu banyak merubah paradigma di bidang ilmu lain. Bahkan walaupun mekanika kuantum sangat revolusioner, diperlukan beberapa tahun kemudian untuk merubah paradigma klasik dalam CMP, perubahan ini juga diawali dengan timbulnya salah satu emergent phenomena superkonduktor yang baru disadari timbul akibat fenomena kuantum. 
Hal ini mengimplikasikan bahwa revolusi paradigma fisika murni tidak akan langsung mempengaruhi paradigma cabang fisika lainnya. Seseorang harus memahami bagaimana pengaruh paradigma dalam suatu disiplin ilmu. Jika suatu paradigma ilmu telah mampu menjelaskan hampir segala fenomena dalam disiplin ilmu itu sendiri, maka sebenarnya tidak ada keharusan untuk merubah pandangan prinsip dasar. Perubahan akan terjadi sesuai dengan apa yang dijelaskan oleh Thomas Kuhn, yakni datangnya anomali dari suatu ilmu yang telah dewasa yang pada akhirnya menuntut adanya perubahan paradigma[3].

Misalnya saja pada fisika, paradigma paling luas dalam fisika saat ini adalah kuantum. Kuantum sendiri timbul akibat serentetan anomali yang ditemukan pada awal tahun 1900an. Selain itu, Model Standar menjadi paradigma dalam ranah fisika partikel, relativitas umum sebagai paradigma kosmologi, central dogma dalam biologi, dan teori Lavoiser dalam reaksi kimia. Mungkin saat ini cukup aman mengatakan bahwa paradigma CMP adalah kuantum dengan menggunakan fisika statistika sebagai pendekatan analisis. Lalu, yang menjadi pertanyaan selanjutnya, apakah tujuan dari ilmu CMP ini?

Mulanya, paradigma dalam CMP adalah mencoba mencari sistem yang sederhana untuk mencari penjelasan fisis dalam benda padat untuk mewakili dan dasar pada sistem yang lebih kompleks. Bahkan sistem yang sederhana tersebut sebenarnya cukup rumit[5]. Namun emergent phenomena akhirnya melibas pandangan tersebut. Kita tidak bisa lagi secara naif mengkonstruksi suatu sistem yang sederhana sebagai generalisasi umum dari sistem yang jauh lebih rumit. Seperti definisi emergent phenomena yang telah disebutkan, setiap kerumitan atau bahkan kecacatan saja yang timbul, akan menghasilkan suatu fenomena atau sifat fisis yang berbeda dari sistem awal yang diprediksi. Misalnya, fenomena efek Hall biasa tidak akan dapat menjelaskan mengapa pada kondisi temperatur rendah dan medan magnet besar, tegangan Hall menjadi terkuantisasi (Quantum Hall Effect). Begitu pula dengan termodinamika dan dinamika fluida tidak akan dapat menjelaskan mengapa Helium cair pada temperatur rendah tidak memiliki viskositasdikenal sebagai superflluidatanpa memperhitungkan kontribusi spin didalamnya. Fenomena timbulnya ferromagnetisme pada material juga tidak dapat dijelaskan secara klasik. Emergent Phenomena akhirnya menjadi puzzle dan arena bermain seorang fisikawan CMP. Konsep inilah yang menjadi rantai roda dalam penelitian CMP. Sehingga bukan lagi unifikasi yang menjadi motivasi para fisikawan di bidang CMP, tetapi mencari fenomena fisis menakjubkan yang dapat timbul akibat konsekuensi kuantum didalamnya. Jika unifikasi adalah ciri khas dari pure physics, maka diversitas adalah ciri khas bidang dirt physics.

Hal yang menarik lainnya adalah jika kita mempertanyakan bagaimana proses suatu sistem memilih keadaan akhirnya, khususnya pada sistem emergent phenomena. Salah satu syarat untuk memodelkan sistem pada fenomena fisika biasanya harus memenuhi konservasi kuantitas pada teorema Noether, dan Hamiltonian yang dirasa dapat mewakili interaksi dalam sistem. Biasanya, Hamiltonian mulanya tidak menunjukkan asimetri. Namun apa yang teramati pada eksperimen maupun perhitungan analitis adalah sistem cenderung memilih keadaan dasar tertentumisalnya pada ferromagnetisme, momen magnetik spin elektron pada kisi atomik cenderung searah menuju arah tertentu. Apa 
yang sebenarnya terjadi? Hal ini timbul akibat proses yang disebut sebagai spontaneous symmetry breaking. Konsep symmetry breaking ini memang pada mulanya berawal dari dunia fisika partikel, yakni Higgs Mechanism, namun semakin berjalannya waktu, symmetry breaking terlihat lebih banyak ditemukan pada CMP. Meminjam sebutan populer dari Adam Smith, maka symmetry breaking adalah invisible-hand nya dalam CMP.

Sebenarnya, sekedar mekanika kuantum saja tidak membantu banyak dalam penjelasan kasus-kasus yang terjadi dalam CMP. Saat ini konsep utama fisika teoritis dalam CMP cenderung juga memerlukan konsep seperti medan kuantum, ini biasanya disebut Quantum Field Theory (QFT). Dari dasar QFT-lah perkembangan pekerjaan teoritis dalam CMP.

Dapat disimpulkan pergeseran paradigma dalam CMP dikarenakan dua konsep diatas, yakni emergent phenomena dan symmetry breaking. Emergent Phenomena menjadi motivasi utama para fisikawan CMP saat ini, yang hal ini sebagian besar diakibatkan oleh proses symmetry breaking diikuti oleh Quantum Field Theory sebagai fondasi utama dalam memandang realitas fenomena yang terjadi didalamnya.

\section{Emergent Phenomena}

Keberadaan CMP dimulai dengan munculnya penelitian di bidang solid-state physics. Tidak ada yang tahu pasti kapan mulai awal berkembangnya solid-state physics, namun dapat dikatakan sebelum tahun 1931 solid-state physics belum dikenal luas, paling tidak dari namanya[5]. Di tahun 1931, Leon Brillouin memperkenalkan konsep potensial periodik dalam kisi kristal yang menghasilkan kesimpulan bahwa terdapat energi elektron yang diperbolehkan dan yang tidak diperbolehkan pada kristal. Namun, tentu saja teori awal kristal tersebut masih belum dapat menjelaskan fenomena superkonduktor yang telah ditemukan lebih awal di tahun 1911.

Berkembangnya bidang CMP sendiri berangsur-angsur sejak mulai meluasnya pengembangan literatur dalam solid-state physics. Banyak fisikawan ingin mempelajari alam di luar keadaan kristal, dan zat padat pada umumnya. Mereka ingin mengembangkan penjelasan pada fenomena-fenomena cairan, sistem disorder, soft-matter, cold atom, bahkan hingga ke ranah biologi, seperti membran.

Fenomena-fenomena di luar prediksi teori terus bermunculan dalam CMP, seperti yang dikatakan sebelumnya bahwa emergent phenomena inilah yang menjadi roda kendali fisikawan teoritis CMP untuk melengkapkan teori-teori yang ada. Fenomena superkonduktor temperatur rendah sendiri baru dapat dijelaskan dalam rentang waktu yang cukup lama ( 50 tahun). Bahkan Einstein dan Werner Heisenberg juga mencoba menjelaskan fenomena ini, namun belum berhasil. Hingga baru tahun 1957, John Bardeen, bersama dua rekannya Cooper dan Schrieffer mempublikasikan teori awal yang cukup sukses untuk menjelaskan Superkonduktor, teori ini disebut BCS (Bardeen-Cooper-Schrieffer) Theory. Siapa yang menyangka bahwa fenomena superkonduktor diakibatkan oleh pasangan elektron yang berinteraksi melalui phonon, dan koherensi keadaan kuantum didalamnya [6].

Sepuluh tahun yang lalunya (1947), transistor berhasil dibentuk di Bell Lab oleh orang 
yang sama, John Bardeen bersama dua rekan yang berbeda, Shockley dan Brattain. Transistor sebagai aplikasi dibidang solid-state physics ini akhirnya merevolusi industri semikonduktor dan prosesor yang menjadi jantung utama komputasi kita hingga saat ini. Maka tak salah hal ini membuat John Bardeen menjadi satu-satunya orang yang mendapat dua nobel fisika, pertama di tahun 1956 atas penemuan transistor, dan kedua tahun 1972 atas keberhasilan teori superkonduktor.

Selain superkonduktor, Emergent Phenomena diluar zat padat yang cukup menakjubkan adalah superfluida, yang diamati pada temperatur rendah. Fenomena superfluida ini diamati pada helium-3 dan helium-4 cair. Fenomena liquid tanpa viskositas dapat merambat tanpa kehilangan energi kinetiknya, layak superkonduktor mengalirkan arus tanpa disipasi energi. Fisikawan yang pertama kali mengembangkan teori superfluida ini adalah fisikawan Rusia bernama Lev Landau. Jawaban atas fenomena superfluida ini adalah bahwa Helium memiliki nilai spin bilangan integer $(n=1,2,3, \ldots)$, sehingga Helium cair ini memenuhi statistik Bose-Einstein[7], yakni satu keadaan kuantum bisa ditempati lebih dari satu partikel.

Superkonduktor dan superfluida sendiri merupakan fenomena akibat koherensi fungsi gelombang kuantum, sehingga teramati pada skala makroskopik. Maka tak salah bahwa pada area ini (disebut sistem mesoskopik) dapat dikatakan sebagai benda kuantum. Analisis yang digunakan biasanya menyeluruh kuantum atau dapat digunakan semi-klasik. Masih berbicara mengenai tokoh Lev Landau, kontribusi yang Ia berikan pada CMP sangat banyak, terutama pada pengembangan fisika statistik dalam CMP. Beberapa diantaranya berkaitan dengan superkonduktivitas tipe II, magnetisme, bahkan hingga menyentuh plasma[4]. Kesuksesan superfluida, dan publikasi lainnya dalam fisika statistik dalam sistem zat padat ataupun liquid, maka dapat dikatakan bahwa Lev Landau adalah salah satu pionir utama dalam CMP.

Selain fenomena super-property yang disebutkan diatas, terdapat juga fenomena besar lain yang mungkin cukup familiar, yakni Quantum Hall Effect (QHE). Fenomena ini menjelaskan kuantisasi konduktivitas hall pada sistem mesoskopik. Konduktivitas yang diberikan merupakan kelipatan dari $e^{2} / h$. Fenomena kuantisasi ini berhasil dijelaskan seorang fisikawan jerman, von Klitzing, yang mendapatkan penghargaan nobel fisika atas capaiannya ini. Tidak berhenti pada kuantisasi bilangan integer $(n=1,2,3, \ldots)$, fenomena lain pada efek hall muncul kembali, yakni Fractional Quantum Hall Effect (FQHE), dimana kelipatan dari suatu nilai fraksi (seperti 1/3, 5/7, dsb). Mekanisme pada FQHE ini tentu lebih rumit dibanding QHE, akibat hasil interaksi elektron-elektron (bukan sekedar interaksi repulsif coulomb biasa, tapi dilihat sebagai komposit elektron)[9]. Fenomena penemuan FQHE diberikan penghargaan nobel fisika kepada tiga orang, yakni Robert Laughlin, Horst Strmer, dan Daniel Tsui.

Puluhan emergent phenomena lain terus ditemukan dalam penilitian. Beberapa fenomena spektakular lainnya adalah Ising Model (menjelaskan interaksi magnetisme dalam material)[10], magnetoresistance, collosal magnetoresistance, quantum dot, superkonduktor temperatur tinggi, Transisi Metal-Insulator, Weyl Fermion, topological material, dan masih banyak lainnya. Beberapa emergent phenomena juga bersinggungan dengan topik ilmu material, seperti material sintetik yang memiliki sifat spektakuler seperti C60 (Buck- 
minsterfullerene), semikonduktor, Alloy, Thin Film, dan tentu juga material Graphene yang mendapatkan penghargaan nobel fisika tahun 2010 yang lalu. Selain ilmu material, juga bersinggungan dengan topik HEP, seperti supersymmetry, time crystal, string theory pada superkonduktor[11], dan tentu masih banyak lagi diluar pengetahuan saya.

Hingga sekarang, kata emergence/emergent menjadi kata sangat populer dalam judul publikasi dalam CMP. Terhitung hingga 10 tahun terakhir telah muncul di ratusan paper dalam jurnal Physical Review Letter[12]. Frasa emergent phenomena mulai di populerkan oleh Philip W. Anderson, seorang fisikawan CMP dan juga peraih nobel, yang menulis artikel More is Different pada majalah Physics Today[13]. Kontribusi Anderson juga tidak kalah besar terhadap dunia CMP (yang paling fenomenal publikasi mengenai Lokalisasi Anderson, dan Symmetry Breaking). Bersama Robert Laughlin, Anderson mempopulerkan dunia CMP pada khalayak ramai, bahkan hingga masyarakat umum. Maka jika dikatakan Landau sebagai pionir CMP, maka Anderson adalah Father of CMP.

Sebagian besar emergent phenomena ini timbul akibat adanya korelasi kuat pada sistem. Dalam sudut pandang interaksi, kita tidak bisa memandang secara naif sistem dapat didekati dari sudut pandang satu elektron atau satu sistem saja. Setiap perubahan gerak elektron misalnya, berkontribusi secara besar terhadap perubahan lingkungannya. Inilah pentingnya pendekatan quasi-partikel pada sistem, dan interaksi didalamnya. Seperti halnya superkonduktor yakni pembawa muatan dipandang sebagai pasangan elektron yang saling berinteraksi tidak langsung, namun melalui perantara phonon.

Hingga sekarang tidak setiap emergent phenomena sudah dijelaskan dengan baik, bahkan sebagian besar masih menjadi misteri bagi fisikawan hingga saat ini. Yang paling fenomenal adalah superkonduktor temperatur tinggi misalnya. Kita tidak dapat menjelaskan fenomena ini dengan teori BCS biasa. Bahkan yang menakjubkan dari fenomena ini adalah, bahwa material superkonduktor temperatur tinggi ini merupakan golongan dari keramik (YBCO), yang secara umum dipandang sebagai insulator. Selain hal tersebut salah satu topik hangat lainnya adalah topological insulator, topological superconductor, yakni fasa material secara topologi yang tahun 2016 lalu tiga orang fisikawan, Kosterlitz, Haldane, dan Thouless berhasil meraih nobel fisika dalam menjelaskan transisi fasa topologi dalam material. Pun masih banyak lagi topik lain dan emergent phenomena yang menarik setiap fisikawan CMP.

Dapat disimpulkan konsep emergent phenomena atau material kuantum, bisa digambarkan seperti skema pada gambar 2 .

\section{Riset dan Komunitas}

Sebagian besar disiplin ilmu, periset dibagi menjadi dua kategori, jika tidak teoritis, berarti eksperimentalis. Begitu pula juga dengan CMP, tidak seperti fisika murni, dua bentuk penelitian ini tidak terpisah terlalu jauh. Hal ini dikarenakan topik-topik riset di CMP harus memilki pengetahuan mengenai proses eksperimen dan teori itu sendiri. Untuk eksperimentalis sendiri, banyak teknik dan alat spektroskopi yang digunakan untuk menganalisis sifat material yang ingin diteliti. Beberapa diantaranya adalah teknik imaging, ARPES, soft x-ray emission, Ultraviolet Photoemission Spectroscopy, dan masih 


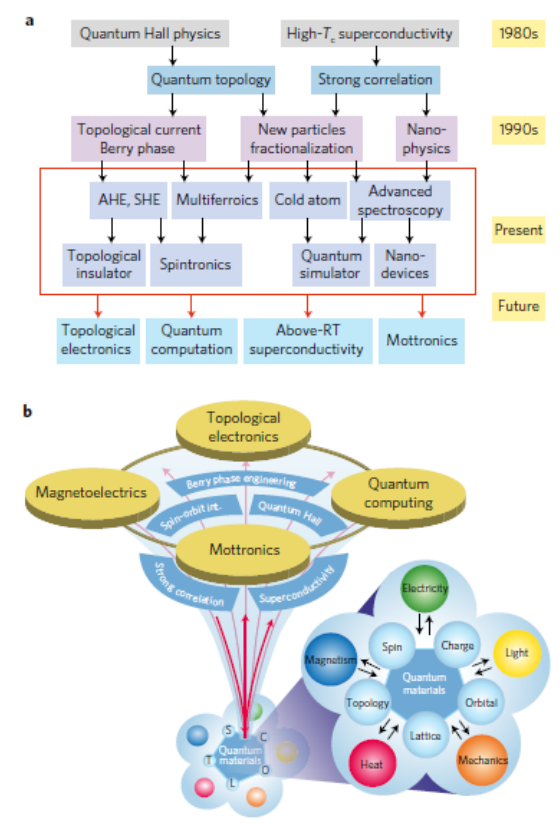

Figure 2: (a).Diagram sejarah perjalanan material quantum, (b) Hubungan properti sistem dengan fenomena yang ditimbulkan ( sumber: lihat ref.[14])

banyak lagi. Sedangkan teoritis juga beragam, ada topik yang dapat dikerjakan dengan analitik dan fisika statistik biasa, namun ada juga yang memerlukan bantuan komputasi yang sangat kompleks.

Perkembangan alat eksperimen dan teknik komputasi yang semakin tinggi pada zaman ini, memiliki dampak yang cukup siginifikan pada dunia CMP. Hal ini tentu karena didasari dari kompleksitas sistem pada CMP. Semakin tingginya teknologi ini membuat semakin dekatnya dunia CMP dengan dunia sehari-hari kita, dimulai dari fenomena material kuantum secara makroskopis, hingga ke ranah sistem self-assembly biologi molekular[4]. Bahkan saat ini state-of-the-art dari computer science, yakni machine learning juga telah merambat ke dalam dunia CMP. Beberapa diantaranya ada yang mencoba mengidentifikasi fasa material dengan teknik dalam machine learning[15, 16]. Bahkan bisa jadi dengan semakin berkembangnya dunia eksperimental, komputasi, dan juga model statistik, mimpi fisikawan CMP untuk dapat memetakan semua fasa material yang mungkin terjadi di alam ini bisa tercapai dalam beberapa dekade lagi[17].

Dilain hal, dikarenakan diversitas topik yang sangat luas di CMP, maka dapat kita temukan grup riset CMP sangat banyak dan bervariasi tergantung fokus topik setiap grup. Tidak salah CMP menjadi komunitas keilmuwan terbesar dalam fisika[18]. Bahkan pertemuan tahunan (march meeting) yang diadakan The American Physical Society telah berkembang hingga 10.000 peserta[19]. Ya, 10 ribu peserta mendiskusikan ratusan topik, riset, dan problem mengenai CMP dalam satu tempat, dan satu waktu! 
Begitu pula dengan peraih Nobel di bidang Fisika. Bidang CMP juga tak kalah banyak dengan fisika murni seperti, astrophysics, cosmology, particle physics. Terdapat 26 peraih nobel Fisika bidang CMP dari tahun 1901 hingga 2017.

\section{Studi CMP untuk Mahasiswa Sarjana}

Untuk memenuhi studi akademik CMP pada tingkat sarjana, sebenarnya topik yang diajarkan hanyalah berkisar pada solid-state physics, belum hingga topik-topik seperti fluida, soft-matter, dsb. Terlebih seorang mahasiswa sarjana CMP juga harus memahami bahwa topik dalam CMP sangat luas sekali dan bercabang, sehingga saya tidak bisa memberikan saran untuk topik mana yang lebih sesuai untuk dijadikan pegangan studi lanjut. Maka dari itu, disini saya coba rangkum saja buku teks, dan silabus untuk mahasiswa sarjana. Yang diharapkan nantinya, dengan proses belajar tersebut, setiap mahasiswa akademik CMP memiliki minat topik nya yang ingin dikembangkan di studi lanjutnya. Pertamatama saya akan mengulas bacaan popular sebelum membahas bacaan studi yang lebih teknis mengenai CMP.

\section{Esai, Artikel, dan Buku Popular mengenai CMP}

1. More is Different by Philip W. Anderson Artikel yang ditulis seorang fisikawan CMP ternama. Artikel ini berisi pandangannya terhadap hirarki sains dan munculnya emergent phenomena akibat kompleksitas sistem.

2. Emergence, causation and storytelling: condensed matter physics and the limitations of the human mind by Stephen J. Blundell

Artikel yang cukup panjang mengenai filosofis dari CMP. Sangat menarik karena ternyata betapa luar biasanya dunia mikroskopis dan betapa naifnya manusia memandang alam.

3. From Big Data To Important Information by Yaneer Bar-Yam

Artikel yang cukup intuitif dalam memahami kompleksitas sistem, terutama dalam ranah physical science, langsung dijelaskan oleh Yaneer Bar-yam salah satu tokoh dalam kompleksitas. Apa itu kompleksitas? bagaimana kita menganalisis sistem yang kompleks. dan yang terpenting adalah bagaimana menemukan skala yang tepat untuk bisa menjelaskan dengan baik perilaku dan properti sistem tanpa harus melibatkan terlalu banyak variabel didalamnya. Dari situ-lah teknik Renormalization Group (teori dalam fisika statistik) dikembangkan, dan Yaner Bar-yam cukup lugas menjelaskan aspek ini.

4. A Different Universe by Robert B. Laughlin

Sebuah buku popular esensial yang harus dibaca untuk memahami CMP. Sangat mudah dipahami oleh orang awam, dan sangat menarik. Buku ini sebagai pintu pembuka yang membuka cakrawala dunia CMP kepada masyarakat umum.

5. Condensed and Material Physics: Basic Research for Tomorrows Technology by Committee On Condensed-Matter And Materials Physics

Sebenarnya ini merupakan saran kebijakan kepada pemerintah untuk mengembangkan sarana dan prasana pada penelitian ilmu material dan CMP. Namun, saran 
kebijakan ini diikuti dengan penjelasan betapa menjanjikannya dan luar biasanya area penelitian material dan CMP ini. Sehingga cocok dijadikan bahan bacaan popular

6. Emergent functions of quantum materials by Yoshinori Tokura, Masashi Kawasaki, and Naoto Nagaosa

Artikel review yang bersifat lebih akademik dan teknis. Membutuhkan beberapa pengetahuan dan wawasan dasar mengenai ilmu CMP untuk memahami artikel ini. Namun disini saya rekomendasikan dikarenakan cukup mereview tantangan material kuantum di masa yang akan datang.

\section{Studi Akademik}

Bagian ini merupakan studi lebih detail dan fokus dalam mendalami CMP. Berikut fondasi dasar yang dibutuhkan untuk mendalami lebih jauh CMP

\section{Fisika Statistik}

- Introductory Statistical Mechanics by Roger Bowley Buku pendahuluan paling intuitif bagi saya, mudah dibaca dan dipahami. Sangat di rekomendasikan untuk pemula dalam fisika statistik. Baiknya, pelajari buku ini lebih dahulu sebelum buku yang lebih tinggi lagi.

- Statistical physics of particles by Mehran Kardar

Lebih teknis, dan detail, tentu dengan matematis yang juga lebih tinggi. Pendekatan modern buku ini juga menarik untuk dijadikan pegangan utama.

- Concepts in thermal physics by Stephen J. Blundell

Buku singkat, dan padat dalam termodinamika + statistik. Buku yang bagus untuk mereview materi-materi dalam fisika statistik.

- Fundamentals of Statistical and Thermal Physics by Frederick Reif Buku pegangan yang sudah berusia tua, namun masih cukup bisa dijadikan pegangan fisika statistik.

\section{Mekanika Kuantum}

- Introduction to Quantum Mechanics by David J. Griffiths

Buku paling esensial yang harus dimiliki seorang mahasiswa sarjana fisika. Bahasa yang sangat mudah dipahami, paling cocok untuk belajar mandiri, dan problem nya sangat penting untuk dikerjakan (jangan pernah skip problem yang diberikan Griffith!)

- Quantum physics by Stephen Gasiorowicz

Buku pegangan alternatif. Terdapat beberapa detail penjelasan yang dimiliki oleh buku ini. Sehingga cocok untuk jadi bahan referensi kedua mekanika kuantum.

\section{Fisika Zat Padat}

- Introduction to Solid State Physics by Charles Kittel

Buku zat padat paling populer saat ini. Materi yang disampaikan sangat sistematis untuk memulai memahami topik zat padat. 
- Solid State Physics by Ashcroft and Mermin

Buku yang cukup populer di kalangan mahasiswa luar negeri selain Kittel, patut dijadikan pegangan bacaan zat padat

- Elementary Solid State Physics: Principles and Applications by M. Ali Omar

Cukup banyak mahasiswa luar merekomendasikan buku ini sebagai pegangan. Hal ini dikarenakan bahasa yang digunakan lebih mudah dicerna dan penjelasannya cukup baik. Dapat dijadikan bacaan alternatif dari Kittel.

\section{Spektroskopi}

- Fundamentals of molecular spectroscopy by C. N. Banwell Buku paling sederhana dalam spektroskopi, dan paling mudah dipahami. Buku ini belum terlalu teknis, sebagian besar menjelaskan konsep bagaimana spektroskopi bekerja.

- Modern Spectroscopy by J. Hollas

Buku yang lebih teknis dalam teknik spektroskopi. Di rekomendasikan untuk jadi bahan bacaan setelah Banwell.

\section{Teori Medan Kuantum untuk CMP}

- A Guide to Feynman Diagrams in the Many-Body Problem by Richard D. Mattuck

Bagi pemula dalam QFT, saya mutlak merekomendasikan buku ini. Layaknya Griffith, buku ini sangat mudah dibaca, dan dipahami. Konsepnya dijelaskan dengan baik tanpa harus banyak menguras tenaga pikiran.

- Quantum Theory of Many-Particle Systems by Alexander L. Fetter and John Dirk Walecka

Ini buku pegangan dalam grup riset TCMP dept. Fisika UI. Namun, saya melihat pendekatan matematis dan notasinya masih menggunakan gaya pedagogik lama fisika tahun abad-20. Sehingga cukup dibutuhkan usaha ekstra untuk memahami setiap halaman buku ini. Namun materi yang diberikan lebih lengkap dan detail dibanding buku Mattuck. 


\section{References}

[1] Feng, Duan, and Jin Guojun. Introduction to Condensed matter Physics. Volume 1. World Scientific, 2005.

[2] Burgess, C.P. An Introduction to Effective Field Theory. Annual Review of Nuclear and Particle Science, vol. 57, no. 1, 2007, pp. 329362., doi:10.1146/annurev.nucl.56.080805.140508.

[3] Kuhn, Thomas S. The Structure of Scientific Revolutions. The University of Chicago Press, 2012.

[4] Condensed-Matter and Materials Physics: Basic Research for Tomorrow's Technology. National Academy Press, 1999.

[5] Cohen, Marvin L. Looking Back and Ahead at Condensed Matter Physics. Physics Today, vol. 59, no. 6, 2006, pp. 4853., doi:10.1063/1.2218555.

[6] Bardeen, J., et al. Theory of Superconductivity. Physical Review, vol. 108, no. 5, 1957, pp. 11751204., doi:10.1103/physrev.108.1175.

[7] Schmitt, Andreas. Introduction to Superfluidity. Lecture Notes in Physics, 2015, doi:10.1007/978-3-319-07947-9.

[8] Sivaram, C,. Kenath, Arun. A Brief Overview of the Major Contribution to Physics by Landau. arXiv:0902.2608

[9] Tong, David. Lectures on the Quantum Hall Effect. 2016. arXiv:1606.06687

[10] Fitzpatrick, Richard. The Ising Model. Richard Fitzpatrick's Academics Site, 2006, http://farside.ph.utexas.edu/teaching/329/lectures/node110.html.

[11] Hartnett, Kevin. Taming Superconductors With String Theory. Quanta Magazine, 2016 January. https://www.quantamagazine.org/ taming-superconductors-with-string-theory-20160121

[12] Blundell, Stephen J. Emergence, causation and storytelling: condensed matter physics and the limitations of the human mind. arXiv:1604.06845

[13] Anderson, P. W. More Is Different. Science, vol. 177, no. 4047, 1972, pp. 393396., doi:10.1126/science.177.4047.393.

[14] Tokura, Y., Kawasaki, M. and Nagaosa, N. Emergent functions of quantum materials. Nature Physics, 13(11), pp.1056-1068. doi:10.1038/nphys4274

[15] Carrasquilla, J. and Melko, R. Machine learning phases of matter. Nature Physics, 13(5), pp.431-434. 2017. doi: 10.1038/nphys4035.

[16] Huembeli, Patrick, et al. Identifying Quantum Phase Transitions with Adversarial Neural Networks. Physical Review B, vol. 97, no. 13, 2018, doi:10.1103/physrevb.97.134109. 
[17] Wolchover, Natalie. Physicists Aim to Classify All Possible Phases of Matter. Quanta Magazine, 2018 January. https://www.quantamagazine.org/ physicists-aim-to-classify-all-possible-phases-of-matter-20180103

[18] Number Of Physics Phds Granted By Subfield From Physics Departments, Classes Of 2010 and 2011 Combined. AIP.Org, 2018.

[19] Warner, Marc., Shulman, Michael. Of Matters Condensed. arXiv:1502.03103 